\title{
Cystatins in non-small cell lung cancer: Tissue levels, localization and relation to prognosis
}

\author{
BERND WERLE ${ }^{1,2}$, ULRIKE SCHANZENBÄCHER ${ }^{1}$, TAMARA TURENSEK LAH ${ }^{5}$, EILEEN EBERT ${ }^{1}$, \\ BRITTA JÜLKE ${ }^{1}$, WERNER EBERT ${ }^{1}$, WERNER FIEHN ${ }^{2}$, KLAUS KAYSER ${ }^{4}$, \\ EBERHARD SPIESS ${ }^{3}$, MAGNUS ABRAHAMSON ${ }^{7}$ and JANKO KOS ${ }^{6}$
}

\begin{abstract}
${ }^{1}$ Abteilung für Klinische Chemie und Bakteriologie, Thoraxklinik Heidelberg gGmbH, Amalienstr. 5, D-69117 Heidelberg;
${ }^{2}$ Zentrallabor des Klinikums, Medizinische Klinik und Poliklinik, Universität Heidelberg, Bergheimerstr. 58, D-69115

Heidelberg; ${ }^{3}$ AG Modellversuche zur Invasion und Metastasierung, Deutsches Krebsforschungszentrum, INF 280,

D-69120 Heidelberg; ${ }^{4}$ Institute of Pathology, Charite, Berlin, Germany; ${ }^{5}$ Department of Genetic Toxicology and Cancer Biology, National Institute of Biology, Vecna pot 111, SLO-1000 Ljubljana; ${ }^{6}$ Faculty of Pharmacy,

Department of Pharmaceutical Biology, University of Ljubljana, Askerceva 7, 1000 Ljubljana, Slovenia;

${ }^{7}$ Department of Clinical Chemistry, University of Lund, University Hospital, S-221 85 Lund, Sweden
\end{abstract}

Received February 9, 2006; Accepted April 17, 2006

\begin{abstract}
Cystatins regulate tumour-associated cysteine proteases, however, their role in tumour progression is not clear yet. To assess their relevance in the progression of nonsmall cell lung cancer (NSCLC) the protein level, cysteine protease activity (CPI) and localization of type I (stefins A and $\mathrm{B}$ ) and type II (C, E/M and F) cystatins were defined in tumours and control lung counterparts from 165 patients. The medians of CPI activity, stefins A and B were significantly greater in tumour than in lung tissue (2.1-fold, 1.7-fold, 1.2fold, respectively, all $\mathrm{p}<0.001)$. The median levels of cystatin $\mathrm{C}$ and cystatin $\mathrm{E} / \mathrm{M}$ were lower in tumour tissue (0.9-fold, $\mathrm{p}=0.06 ; 0.6$-fold, $\mathrm{p}<0.01)$. In all the samples the levels of cystatin $\mathrm{F}$ were below the detection limit. Immunohistochemical analysis revealed the presence of all cystatins in tumour cells and infiltrated inflammatory cells such as macrophages and neutrophils. In univariate survival analysis patients with high levels of stefin A, stefin B and CPI activity exhibited a better survival probability $(\mathrm{p}=0.05, \mathrm{p}=0.05$, $\mathrm{p}<0.01$, respectively). In contrast, cystatins $\mathrm{C}$ and $\mathrm{E} / \mathrm{M}$ provided no prognostic information. In multivariate analysis the most powerful predictor of survival was the pTNM stage ( $<<0.0001$; RR 3.5), followed by stefin A, stefin B and CPI activity (all $p=0.03$; RR 1.5 ). Our results suggest that only stefins A and B, i.e. type I cystatins, are up-regulated in lung
\end{abstract}

Correspondence to: Professor Janko Kos, Faculty of Pharmacy, Department of Pharmaceutical Biology, University of Ljubljana, Askerceva 7, SI-1000 Ljubljana, Slovenia

E-mail: janko.kos@ffa.uni-lj.si

Key words: stefin, cystatin, cysteine protease, cathepsin, non-small cell lung cancer, prognosis tumours and thus able to counteract harmful tumourassociated proteolytic activity. As biological markers they may add independent prognostic information for better assessment of low- and high-risk patients with NSCLC.

\section{Introduction}

Cystatins, the cysteine protease-inhibitors, comprise a superfamily of evolutionarily related proteins, each consisting of at least one domain of 100-120 amino acid residues with conserved sequence motifs (1). Type I cystatins, stefins A and $\mathrm{B}$, are cytosolic, $\sim 100$ amino acid residue proteins with no disulphide bridges. Type II cystatins, C, D, E/M, F, S, SA and $\mathrm{SN}$ are extracellular proteins, consisting of $\sim 120$ amino acid residues and containing two disulphide bridges. Type III cystatins, the kininogens, are large multifunctional plasma proteins, containing three type II cystatin-like domains.

A broad spectrum of biological roles have been suggested for cystatins, including protein catabolism, regulation of hormone processing and bone resorption, inflammation, antigen presentation and T-cell-dependent immune response $(2,3)$ as well as resistance to various bacterial and viral infections. In most cases cystatins function as reversible, tight-binding inhibitors of cysteine proteases, however, they can also act in a manner independent of their inhibitory properties (4-7). Cystatins have been suggested to be involved in the alteration of the proteolytic system in several diseases, including cancer $(2,8)$. Mutations in the gene encoding stefin B have been linked to progressive myoclonous epilepsy (EPM1) (9) and, in the gene for cystatin C, with hereditary cystatin C amyloid angiopathy (10).

In lung tumours the protein concentration and enzymatic activity of cysteine proteases, in particular cathepsins B and $\mathrm{L}$ have been shown to be significantly higher than in their control lung counterparts (11-17). These increased levels were not balanced with a corresponding increase of the cystatins. 
Total CPI activity in tumours has been reported to be increased (18), unchanged (19) and lower $(20,21)$ with respect to matched control tissue. For individual cystatins we found increased protein levels for stefins $\mathrm{A}$ and $\mathrm{B}$, but decreased levels for cystatin $C$ (22). For the latter we suggested that its inhibitory capability is hindered during cancer progression since the cathepsin B/cystatin C complex was significantly less abundant in the sera of patients bearing malignant lung tumours than in those with non-cancerous lung diseases (23). Survival analysis on a limited number of patients showed a correlation of high CPI activity and stefin B levels with lower risk of death in NSCLC patients (22).

To further our understanding of the role of individual cystatins in lung tumours, we examined five cystatins, stefins $\mathrm{A}$ and $\mathrm{B}$, and cystatins $\mathrm{C}, \mathrm{E} / \mathrm{M}$ and $\mathrm{F}$, in a cohort of 165 patients with NSCLC. Cystatin protein levels were measured in matched pairs of tumour and adjacent lung parenchyma, and their cellular localization was determined on selected tissue sections. To evaluate their prognostic relevance, the protein levels of cystatins were correlated with histological and clinical parameters of advanced disease in the group of NSCLC patients after a seven-year observation period.

\section{Patients and methods}

Patients. Tumour and non-cancerous lung tissues were obtained as matched pairs from each of the 165 patients with lung tumours, resected by surgery at the Thoraxhospital, Heidelberg, gGmbH. The age of the patients ranged from 15 to 81 years (median: 59 years). Whenever macroscopically possible, tumour tissue was resected in the periphery of the tumour. The necrotic parts of the tumour were removed. Non-cancerous adjacent lung tissue was taken from areas at least $6 \mathrm{~cm}$ away from the tumour. Tissue homogenates were prepared as described elsewhere (15).

Based on the predominant cell type, lung tumours were grouped according to the WHO classification. The tumour disease stage (pTNM) was classified according to the international staging system (UICC 1987). All patients included in this study had been subjected to primary surgery. Twenty patients with pTNM IIIb and 13 patients with pTNM IV, underwent curative surgery presumably due to incorrect preoperative clinical staging (cTNM) or to individually favourable conditions. None of the patients received chemotherapy or was exposed to radiation therapy prior to surgery. After surgery, only low-stage patients were observed, while highstage patients received adjuvant or palliative chemotherapy and/or radiation therapy according to current therapy guidelines $(24,25)$. The median follow-up of patients still alive at the time of analysis was 46 (9-89) months. This study was carried out with local ethics committee approval.

Immunohistochemical analysis. To visualize the cystatins in tissue sections, a highly sensitive staining protocol was applied, using the following primary antibodies: mouse $\mathrm{C} 5 / 2$ MAb, A6/2 MAb and 1A2 MAb for stefin A, stefin B and cystatin $\mathrm{C}$, respectively (Krka, d.d., Slovenia), and rabbit PAbs against cystatin E/M and cystatin F (M.A., Lund University, Sweden). Sections (3-5 $\mu \mathrm{m})$ from formalin-fixed, paraffinembedded tumour tissues were used for immunohistochemical analysis (26). Lung tumour tissue sections were deparaffinized by xylene $(2 \times 5 \mathrm{~min})$ and rehydrated through alcohol $99 \%$

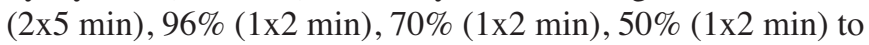
phosphate buffered saline (PBS), pH 7.4 (3x3 min). After blocking of endogenous peroxidase with $2 \%$ methanolic hydrogen peroxide for $15 \mathrm{~min}$ and non-specific binding with $5 \%$ normal goat serum in PBS for $30 \mathrm{~min}$ at room temperature, tissue sections were rinsed in PBS ( $3 \times 3 \mathrm{~min})$ and incubated with an appropriate dilution of anti-cystatin antibody in PBS, containing 5\% normal goat serum, in a humid chamber at room temperature overnight. After washing with PBS $(3 \times 3 \mathrm{~min})$, tissue sections were incubated with biotinylated secondary antibody (Vector Laboratories, Serva Heidelberg, Germany) in PBS with 5\% normal goat serum for $30 \mathrm{~min}$ and then with the Vectastain ABC Reagent (Vector) for another $30 \mathrm{~min}$. Peroxidase activity was developed with 3,3'-diaminobenzidine tetrahydrochloide $(0.3 \mathrm{mg} / \mathrm{ml}$ in $0.05 \mathrm{M}$ Tris-buffer, $\mathrm{pH} 7.5$ ), including $0.2 \%$ hydrogen peroxide for $10-15 \mathrm{~min}$. Finally, tissue sections were lightly counterstained with $5 \%$ Harris's hematoxylin, dehydrated, and mounted.

The following control assays were performed: i) incubation as in the assay, omitting the primary antibody, ii) incubation omitting the secondary antibody, iii) pre-adsorption of the antigen (stefins A, B, cystatin C) with the antibody in 1:3 molar ratio prior the assay. Tissue sections were inspected by the pathologist (K. K.).

Determination of protein concentration. Protein concentration was determined according to Bradford (27). Bovine serum albumin was used as a standard.

Determination of CPI activity. CPI activity was determined according to Ebert et al (28). Two hundred and fifty microliters of $200 \mathrm{mM}$ phosphate buffer containing $4 \mathrm{mM}$ EDTA and freshly prepared DTT (final concentration $4 \mathrm{mM}$ ), and $100 \mu 1$ of $8 \mathrm{nM}$ papain (final concentration) were incubated together with $100 \mu \mathrm{l}$ of the inhibitor for $10 \mathrm{~min}$ at $40^{\circ} \mathrm{C}$. Then $20 \mathrm{mM}$ of phosphate buffer was added to a final volume of $975 \mu \mathrm{l}$. After $5 \mathrm{~min}$ incubation at $25^{\circ} \mathrm{C}, 25 \mu \mathrm{l} \mathrm{Z}$-Phe-Argaminomethyl-coumarine (AMC) was added ( $5 \mu \mathrm{M}$ final concentration). Fluorescence was measured at $460 \mathrm{~nm}$ in an LS-3B Fluorescence Spectrometer (Perkin-Elmer), with excitation at $370 \mathrm{~nm}$. The amount of liberated AMC and consequently the papain activity was calculated using a standard curve. One inhibitory unit (IU) was defined as the amount of inhibitor which inactivated $1 \mathrm{~mol}$ of papain (EU). Specific activity was expressed in IU per $\mathrm{mg}$ protein $(\mathrm{IU} / \mathrm{mg}$ protein).

ELISAs. Stefins A and B were quantitated by using commercially available assays (Krka). The monoclonal antibodies used in the assays recognized native and recombinant antigens equally well. Monoclonal antibodies C5/2 MAb to stefin A and E7/1 MAb to stefin B bound both the complex and free inhibitors, whereas $A 2 / 2 \mathrm{MAb}$ to stefin $\mathrm{A}$ and $\mathrm{A} 6 / 2 \mathrm{MAb}$ to stefin B preferentially bound free inhibitors (29). In both assays cytosols in a 1:50 dilution were added to the wells of a microtiter plate, pre-coated with the capture antibody (C5/2 MAb for stefin A, A6/2 MAb for stefin $\mathrm{B}$ ). After $2 \mathrm{~h}$ incubation at $37^{\circ} \mathrm{C}$, the wells were 
Table I. Stefin A and stefin B level in tissue homogenates of tumours and lung parenchyma of patients with NSCLC.

\begin{tabular}{|c|c|c|c|c|c|c|c|c|}
\hline & \multicolumn{3}{|c|}{$\begin{array}{l}\text { Stefin A } \\
\left(\text { ngmg }^{-1} \text { protein }\right)\end{array}$} & \multirow[b]{2}{*}{$\begin{array}{c}\mathrm{Tu} / \mathrm{Lu} \\
\text { ratio }\end{array}$} & \multicolumn{3}{|c|}{$\begin{array}{l}\text { Stefin B } \\
\text { (ngmg }^{-1} \text { protein) }\end{array}$} & \multirow[b]{2}{*}{$\begin{array}{r}\mathrm{Tu} / \mathrm{Lu} \\
\text { ratio }\end{array}$} \\
\hline & $\mathrm{n}$ & $\begin{array}{c}\text { Tumour } \\
\text { median } \\
(5 \%, 95 \%)\end{array}$ & $\begin{array}{c}\text { Normal } \\
\text { median } \\
(5 \%, 95 \%)\end{array}$ & & $\mathrm{n}$ & $\begin{array}{c}\text { Tumour } \\
\text { median } \\
(5 \%, 95 \%)\end{array}$ & $\begin{array}{l}\text { Normal } \\
\text { median } \\
(5 \%, 95 \%)\end{array}$ & \\
\hline Lung tumours (total) & 136 & $\begin{array}{l}97 \\
(15,938)\end{array}$ & $\begin{array}{l}56 \\
(21,127)\end{array}$ & 1.7 & 165 & $\begin{array}{l}150 \\
(22,518)\end{array}$ & $\begin{array}{l}124 \\
(24,320)\end{array}$ & 1.2 \\
\hline Primary tumours (NSCLC) & 111 & $\begin{array}{l}108 \\
(18,943)\end{array}$ & $\begin{array}{l}59 \\
(22,118)\end{array}$ & 1.8 & 142 & $\begin{array}{l}153 \\
(20,512)\end{array}$ & $\begin{array}{l}124 \\
(24,320)\end{array}$ & 1.2 \\
\hline Squamous cell carcinoma & 48 & $\begin{array}{l}317 \\
(72,1635)\end{array}$ & $\begin{array}{l}55 \\
18,128)\end{array}$ & 5.8 & 66 & $\begin{array}{l}155 \\
(10,588)\end{array}$ & $\begin{array}{l}114 \\
(24,348)\end{array}$ & 1.3 \\
\hline Adenocarcinoma & 53 & $\begin{array}{c}69 \\
(18,171)\end{array}$ & $\begin{array}{l}54 \\
(22,112)\end{array}$ & 1.3 & 60 & $\begin{array}{l}150 \\
(27,386)\end{array}$ & $\begin{array}{l}120 \\
(20,317)\end{array}$ & 1.3 \\
\hline Large cell carcinoma & 6 & $\begin{array}{l}143 \\
(32,193)\end{array}$ & $\begin{array}{l}78 \\
(54,173)\end{array}$ & 1.8 & 6 & $\begin{array}{l}299 \\
(30,418)\end{array}$ & $\begin{array}{l}200 \\
(152,404)\end{array}$ & 1.5 \\
\hline Carcinoids & 4 & $\begin{array}{l}35 \\
(8,105)\end{array}$ & $\begin{array}{l}44 \\
(14,109)\end{array}$ & 0.8 & 6 & $\begin{array}{l}246 \\
(82,374)\end{array}$ & $\begin{array}{l}153 \\
(18,294)\end{array}$ & 1.6 \\
\hline Secondary tumours & 21 & $\begin{array}{l}47 \\
(14,136)\end{array}$ & $\begin{array}{l}51 \\
(21,136)\end{array}$ & 0.9 & 21 & $\begin{array}{l}146 \\
(44,518)\end{array}$ & $\begin{array}{l}110 \\
(46,276)\end{array}$ & 1.3 \\
\hline
\end{tabular}

washed and filled with secondary antibody conjugated to HRP (2A2 MAb for stefin A, E7/1 for stefin B). After a further $2 \mathrm{~h}$ incubation at $37^{\circ} \mathrm{C}$, peroxidase substrate $3,3,5,5$ tetramethyl benzidine (Sigma, St. Louis, USA) in the presence of hydrogen peroxide was added. The amount of degraded substrate was visualized by absorbance at $450 \mathrm{~nm}$, and the concentration of stefin were calculated from the calibration curve. The detection limit of the assay was 0.8 $\mathrm{ngml}^{-1}$ for stefin A and $0.6 \mathrm{ngml}^{-1}$ for stefin B.

Cystatins $\mathrm{C}, \mathrm{E} / \mathrm{M}$, and $\mathrm{F}$ were quantitated according to the procedures developed by Olafsson et al (30) and $\mathrm{Ni}$ et al $(31,32)$. A polyclonal rabbit antiserum raised against individual recombinant human cystatin recognized free inhibitor and enzyme-inhibitor complexes. The specificity of the antiserum was tested by immunoelectrophoresis of concentrated proteinuria urine containing stefins $\mathrm{A}$ and $\mathrm{B}$ and cystatins $\mathrm{C}$, $\mathrm{S}, \mathrm{SN}$, kininogen, and added recombinant cystatins $\mathrm{C}, \mathrm{D}$, and $\mathrm{F}$. The IgG fraction from the antiserum was isolated and used in a double sandwich ELISA. Wells in polystyrene microtiter plates (MaxiSorp, Nunc, Copenhagen, Denmark) were coated with the $\mathrm{IgG}$ fraction. Samples or recombinant cystatins as calibrators, were added to the wells. After $2 \mathrm{~h}$ incubation at $37^{\circ} \mathrm{C}$ the wells were washed and filled with biotinylated IgG fraction. Bound cystatin was quantified using a streptavidinHRP conjugate (Amersham Pharmacia Biotech) using 2,2azino-di-(3-ethyl-benzothiazolin-sulfonate and hydrogen peroxide as substrate (Sigma, Munich, Germany). The absorbance was read at $405 \mathrm{~nm}$ in a Titerek Multiscan spectrophotometer.

The detection limit for cystatin $\mathrm{C}$ was $0.5 \mathrm{ngml}^{-1}$, for cystatin E/M $5 \mathrm{pgml}^{-1}$ and for cystatin $\mathrm{F} 10 \mathrm{pgml}^{-1}$.
Statistical analyses. To compare paired data of tumour and non-cancerous lung tissue, two-tailed Wilcoxon's rank test was used. Differences in cystatin content and CPI activity between different subgroups of patients were tested by the Mann-Whitney and Kruskall-Wallis tests. Correlations between CPI activity and cystatin protein concentrations were calculated by non-parametric regression analysis and the significance of the Spearman rank correlation coefficient was evaluated by analysis of variance (ANOVA).

Univariate analysis of survival probability was performed by Kaplan-Meier analysis (33), using log-rank test to determine statistical significance between the survival curves. Multivariate analysis was performed using the Cox proportional hazard model (34) and a stepwise forward logistic regression approach. The discrimination levels to differentiate between the subgroups of patients were calculated by the Critlevel program (35). Several statistical packages (PC-Statistik by TOPSOFT, Hannover, Germany; Statistika by Statsoft, Hamburg, Germany, and SPSS by SPSS Inc., Chicago, IL) were applied.

\section{Results}

CPI activity and protein levels of stefins and cystatins in lung tumours and parenchyma. The medians of CPI activity and protein levels of stefin A, stefin B, cystatin $\mathrm{C}$ and cystatin $\mathrm{E} / \mathrm{M}$ in a corresponding number of homogenates of lung tumours and matched lung parenchyma are listed in Tables I and II. The levels of cystatin F were all below the detection limit of the assay. 
Table II. Cysteine protease-inhibitory activity (CPI), cystatin $\mathrm{C}$ and cystatin $\mathrm{E} / \mathrm{M}$ in tissue homogenates of tumours and normal lung parenchyma of patients with NSCLC.

\begin{tabular}{|c|c|c|c|c|c|c|c|c|c|c|c|c|}
\hline & \multicolumn{3}{|c|}{$\begin{array}{l}\text { CPI activity } \\
\left(\mu \mathrm{IUmg}^{-1} \text { protein }^{-1}\right)\end{array}$} & \multirow[b]{2}{*}{$\begin{array}{c}\mathrm{Tu} / \mathrm{Lu} \\
\text { ratio }\end{array}$} & \multicolumn{4}{|c|}{$\begin{array}{l}\text { Cystatin C } \\
\left(\text { ngmg }^{-1} \text { protein }^{-1}\right)\end{array}$} & \multicolumn{3}{|c|}{$\begin{array}{l}\text { Cystatin E/M } \\
\left(\text { pgmg }^{-1} \text { protein }^{-1}\right)\end{array}$} & \multirow[b]{2}{*}{$\begin{array}{c}\mathrm{Tu} / \mathrm{Lu} \\
\text { ratio }\end{array}$} \\
\hline & $\mathrm{n}$ & $\begin{array}{l}\text { Tumour } \\
\text { median } \\
(5 \%, 95 \%)\end{array}$ & $\begin{array}{c}\text { Normal } \\
\text { median } \\
(5 \%, 95 \%)\end{array}$ & & $\mathrm{n}$ & $\begin{array}{l}\text { Tumour } \\
\text { median } \\
(5 \%, 95 \%)\end{array}$ & $\begin{array}{l}\text { Normal } \\
\text { median } \\
(5 \%, 95 \%)\end{array}$ & $\begin{array}{l}\mathrm{Tu} / \mathrm{Lu} \\
\text { ratio }\end{array}$ & $\mathrm{n}$ & $\begin{array}{l}\text { Tumour } \\
\text { median } \\
(5 \%, 95 \%)\end{array}$ & $\begin{array}{l}\text { Normal } \\
\text { median } \\
(5 \%, 95 \%)\end{array}$ & \\
\hline $\begin{array}{l}\text { Lung tumours } \\
\text { (total) }\end{array}$ & 97 & $\begin{array}{l}936 \\
(341,4248)\end{array}$ & $\begin{array}{l}445 \\
(168,1408)\end{array}$ & 2.1 & 101 & $\begin{array}{l}3.8 \\
(0.7,45)\end{array}$ & $\begin{array}{l}4.1 \\
(1.7,13.4)\end{array}$ & 0.9 & 48 & $\begin{array}{l}13.9 \\
(2.8,59.1)\end{array}$ & $\begin{array}{l}22.6 \\
(9.2,46.4)\end{array}$ & 0.62 \\
\hline $\begin{array}{l}\text { Primary tumours } \\
\text { (NSCLC) }\end{array}$ & 79 & $\begin{array}{l}1029 \\
(341,4545)\end{array}$ & $\begin{array}{l}455 \\
(140,1607)\end{array}$ & 2.3 & 82 & $\begin{array}{l}3.7 \\
(0.7,45.1)\end{array}$ & $\begin{array}{l}4.1 \\
(1.7,15.6)\end{array}$ & 0.9 & 38 & $\begin{array}{l}14.6 \\
(3.5,69.1)\end{array}$ & $\begin{array}{l}22.2 \\
(8.2,42.9)\end{array}$ & 0.66 \\
\hline $\begin{array}{l}\text { Squamous cell } \\
\text { carcinoma }\end{array}$ & 40 & $\begin{array}{l}1271 \\
(474,4892)\end{array}$ & $\begin{array}{l}427 \\
(111,1081)\end{array}$ & 3 & 41 & $\begin{array}{l}3.3 \\
(0.7,13)\end{array}$ & $\begin{array}{l}4.1 \\
(1.8,18)\end{array}$ & 0.8 & 21 & $\begin{array}{l}12.7 \\
(3.5,34.5)\end{array}$ & $\begin{array}{l}21.7 \\
(11.6,42.7)\end{array}$ & 0.58 \\
\hline Adenocarcinoma & 26 & $\begin{array}{l}764 \\
(249,2135)\end{array}$ & $\begin{array}{l}454 \\
(193,1775)\end{array}$ & 1.7 & 28 & $\begin{array}{l}4.5 \\
(1.3,48.6)\end{array}$ & $\begin{array}{l}4.9 \\
(1.7,13)\end{array}$ & 0.9 & 11 & $\begin{array}{l}17.5 \\
(9.5,69.1)\end{array}$ & $\begin{array}{l}23.3 \\
(4.4,57.7)\end{array}$ & 0.75 \\
\hline $\begin{array}{l}\text { Large cell } \\
\text { carcinoma }\end{array}$ & 6 & $\begin{array}{l}964 \\
(560,1632)\end{array}$ & $\begin{array}{l}570 \\
(300,1617)\end{array}$ & 1.7 & 6 & $\begin{array}{l}2.6 \\
(0.4,8.4)\end{array}$ & $\begin{array}{l}3.6 \\
(1.6,5.1)\end{array}$ & 0.7 & 3 & $\begin{array}{l}8.9 \\
(7.3,28)\end{array}$ & $\begin{array}{l}22.9 \\
(12,27.9)\end{array}$ & 0.39 \\
\hline Carcinoids & 5 & $\begin{array}{l}594 \\
(342,2418)\end{array}$ & $\begin{array}{l}334 \\
(167,460)\end{array}$ & 1.8 & 5 & $\begin{array}{l}45.1 \\
(1.6,167)\end{array}$ & $\begin{array}{l}3.3 \\
(3,8.8)\end{array}$ & 1.2 & 3 & $\begin{array}{l}27.9 \\
(17.9,59.1)\end{array}$ & $\begin{array}{l}22.2 \\
(12.4,31.1)\end{array}$ & 1.26 \\
\hline Secondary tumours & 20 & $\begin{array}{l}780 \\
(303,2698)\end{array}$ & $\begin{array}{l}429 \\
(239,1600)\end{array}$ & 1.8 & 21 & $\begin{array}{c}4.4 \\
(0.8,30)\end{array}$ & $\begin{array}{l}4.7 \\
(3.3,9.5)\end{array}$ & 0.9 & 10 & $\begin{array}{l}11.6 \\
(1.7,26.9)\end{array}$ & $\begin{array}{l}32.1 \\
(11.3,65.8)\end{array}$ & 0.36 \\
\hline
\end{tabular}

The median levels of CPI activity, and stefins A and stefin B were significantly higher in tumour tissue than in the corresponding lung parenchyma $(2.1$-fold, 1.7-fold and 1.2fold, respectively, $\mathrm{p}<0.001)$. In contrast, the median levels of cystatin $\mathrm{C}$ and cystatin $\mathrm{E} / \mathrm{M}$ were lower in tumour tissue than in the corresponding lung parenchyma $(\mathrm{p}=0.06 ; \mathrm{p}<0.01$, respectively). Only stefin A levels were significantly higher in primary tumours than in secondary lung tumours $(\mathrm{p}<0.01)$. In tumour tissue, the level of stefin $B$ was higher than that of stefin $\mathrm{A}(\mathrm{p}<0.01)$, cystatin $\mathrm{C}(\mathrm{p}<0.01)$ and cystatin $\mathrm{E} / \mathrm{M}$ $(\mathrm{p}<0.01)$. Regarding the histological cell type, CPI activity and stefin A concentration were significantly higher in SCC than in AC (all $\mathrm{p}<0.01$ ). Remarkably, carcinoids, low grade neoplasms, exhibited low stefin A and high cystatin $\mathrm{C}$ values. There were no significant differences in CPI activity and the concentrations of stefins $\mathrm{A}$ and $\mathrm{B}$, and cystatins $\mathrm{C}$, and $\mathrm{E} / \mathrm{M}$ as a function of pTNM-stage. Regarding cell differentiation, only stefin A concentration was higher in poorly differentiated tumours (G3) than in well and moderately differentiated cells (G1/G2), (112 vs 68 ngmg $^{-1}$ protein, $\mathrm{p}<0.01$ ).

Correlations between cystatin levels and CPI activity. In NSCLC, the levels of stefins A and B correlated with CPI activity $(\mathrm{p}<0.01, \mathrm{r}=0.4 ; \mathrm{p}<0.05, \mathrm{r}=0.27$, respectively). A weak correlation was observed between stefins A and B $(\mathrm{p}<0.05$, $\mathrm{r}=0.3$ ). There was no correlation between cystatins $\mathrm{C}, \mathrm{E} / \mathrm{M}$ and stefins $\mathrm{A}$ and $\mathrm{B}$ or between cystatins $\mathrm{C}, \mathrm{E} / \mathrm{M}$ and $\mathrm{CPI}$ activity. In lung tissue no correlation between cystatins was observed.
Stefin A levels were validated in 43 matched pairs of tumour and adjacent lung parenchyma by using another commercially available ELISA (BioAss, Diessen, Germany). A good correlation was obtained between stefin A values measured by ELISAs from Krka and from BioAss $(\mathrm{P}<0.01$, $\mathrm{r}=0.73, \mathrm{n}=86$ ).

Cellular distribution of cystatins in tumours. Tumours with high protein levels of a particular cystatin were selected for immunohistochemical analysis. Immunohistochemical staining of cystatins in lung tumours of different origin is shown in Fig. 1.

Stefins A and B were expressed in tumour cells of SCC and AC. Inflammatory cells such as histiocytes and pneumocytes type II also stained positive for both inhibitors (Fig. 1A-D). Similarly, cystatins C, E/M and F can be detected in tumour cells of SCC and AC (Fig. 1E-H). Cystatin C was also localized in inflammatory lung parenchyma, being markedly higher in infiltrated macrophages than in neutrophils (Fig. 1E). In addition, 1-2\% of lymphocytes stained positive for cystatin C. Cystatins $\mathrm{E} / \mathrm{M}$ and $\mathrm{F}$ were also present in tumour cells and in inflammatory cells such as macrophages and neutrophils (Fig. $1 \mathrm{G}$ and $\mathrm{H}$ ).

Univariate and multivariate survival analyses. Univariate analysis of NSCLC patients showed CPI activity, and stefins $\mathrm{A}$ and $\mathrm{B}$ to have a significant prognostic value over a 7-year observation period (Table III). Notably, patients with high inhibitory activity or protein levels had a better prognosis 

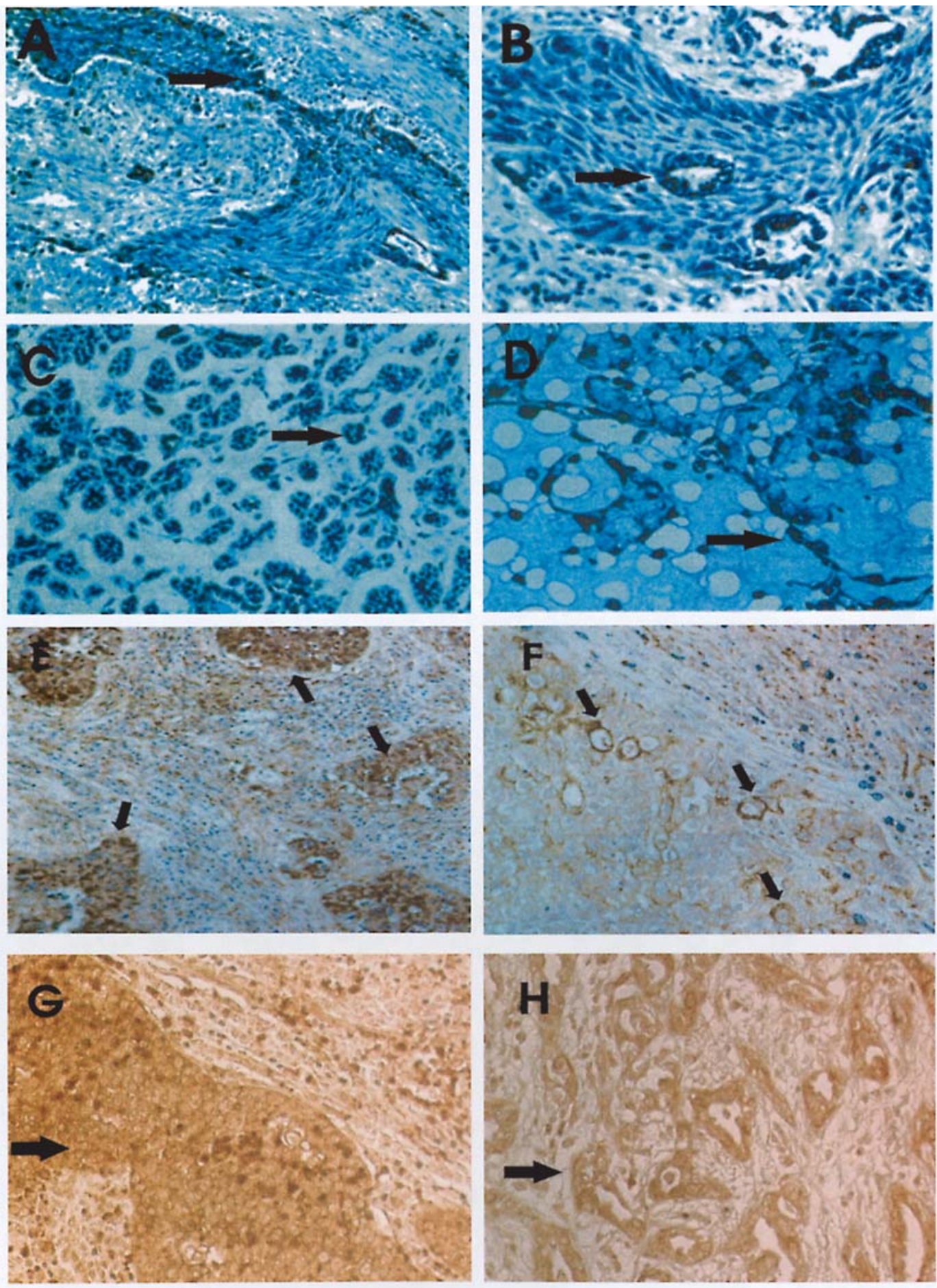

Figure 1. Immunohistochemical analysis of stefins $\mathrm{A}$ and $\mathrm{B}$ and cystatins $\mathrm{C}, \mathrm{E} / \mathrm{M}$ and $\mathrm{F}$ in tumour tissue sections from patients with NSCLC. (A) Stefin A in SCC. (B) Stefin A in AC. (C) Stefin B in AC. (D) Stefin B in AC. (E) Cystatin C in SCC. (F) Cystatin C in SCC. (G) Cystatin E/M in AC. (H) Cystatin F in SCC. In most of the tissue sections cystatin staining was found in the cytoplasm of tumour cells and the surrounding histiocytes. Arrows indicate the cells stained most intensely for the particular cystatin. Magnification x 312 .

than patients with low levels in all three cases. A similar result was found in a subgroup of patients with SCC (Fig. 2), whereas in patients with AC, only CPI activity and stefin B remained significant predictive factors. Cystatin $\mathrm{C}$ and $\mathrm{E} / \mathrm{M}$ levels did not correlate with the survival of lung cancer patients, either in the study group of patients with NSCLC or in the subgroups of patients with SCC or AC.

In multivariate analysis, only those factors having a significant impact on overall survival probability in univariate analysis were included (Table IV). pTNM-staging was the most powerful predictor of survival in NSCLC patients. CPI activity, and stefins $\mathrm{A}$ and $\mathrm{B}$ remained significant and independent prognostic factors with equal prognostic value.

\section{Discussion}

It has been suggested that in cancer, the increased levels of cysteine protease activity, not being balanced by a 
Table III. Univariate survival analysis of cystatins in NSCLC patients.

\begin{tabular}{|c|c|c|c|}
\hline & Variable & Favourable vs unfavourable characteristics & P-value \\
\hline \multirow[t]{5}{*}{ NSCLC } & CPI activity & $>1131$ vs $<1131 \mu 1 \mathrm{Umg}^{-1}$ protein $^{-1}$ & 0.05 \\
\hline & Stefin A & $>560$ vs $<560$ ngmg $^{-1}$ protein $^{-1}$ & 0.05 \\
\hline & Stefin B & $>91$ vs $<91$ ngmg $^{-1}$ protein $^{-1}$ & $<0.01$ \\
\hline & Cystatin $\mathrm{C}$ & $>3.8$ vs $<3.8$ ngmg $^{-1}$ protein $^{-1}$ & 0.08 \\
\hline & Cystatin E/M & $>13.9$ vs $<13.9$ pgmg $^{-1}$ protein $^{-1}$ & 0.5 \\
\hline \multirow[t]{5}{*}{$\mathrm{SCC}$} & CPI activity & $>1213$ vs $<1213 \mu \mathrm{lUmmg}^{-1}$ protein $^{-1}$ & $<0.01$ \\
\hline & Stefin A & $>560$ vs $<560$ ngmg $^{-1}$ protein $^{-1}$ & 0.03 \\
\hline & Stefin B & $>91$ vs $<91$ ngmg $^{-1}$ protein $^{-1}$ & $<0.01$ \\
\hline & Cystatin C & $>3.8$ vs $<3.8$ ngmg $^{-1}$ protein $^{-1}$ & 0.1 \\
\hline & Cystatin E/M & $>13.9$ vs $<13.9$ pgmg $^{-1}$ protein $^{-1}$ & 0.6 \\
\hline \multirow[t]{5}{*}{$\mathrm{AC}$} & CPI activity & $>581$ vs $<581 \mu 1 \mathrm{Umg}^{-1}$ protein $^{-1}$ & 0.05 \\
\hline & Stefin A(ngmg $\left.{ }^{-1}\right)$ & $>71 \mathrm{vs}^{2}>71 \mathrm{ngmg}^{-1}$ protein $^{-1}$ & 0.09 \\
\hline & Stefin B (ngmg $\left.{ }^{-1}\right)$ & $>90$ vs $<90$ ngmg $^{-1}$ protein $^{-1}$ & 0.05 \\
\hline & Cystatin C & $>3.8$ vs $<3.8$ ngmg $^{-1}$ protein $^{-1}$ & 0.1 \\
\hline & Cystatin E/M & $>13.9$ vs $<13.9 \mathrm{pgmg}^{-1}$ protein $^{-1}$ & 0.5 \\
\hline
\end{tabular}
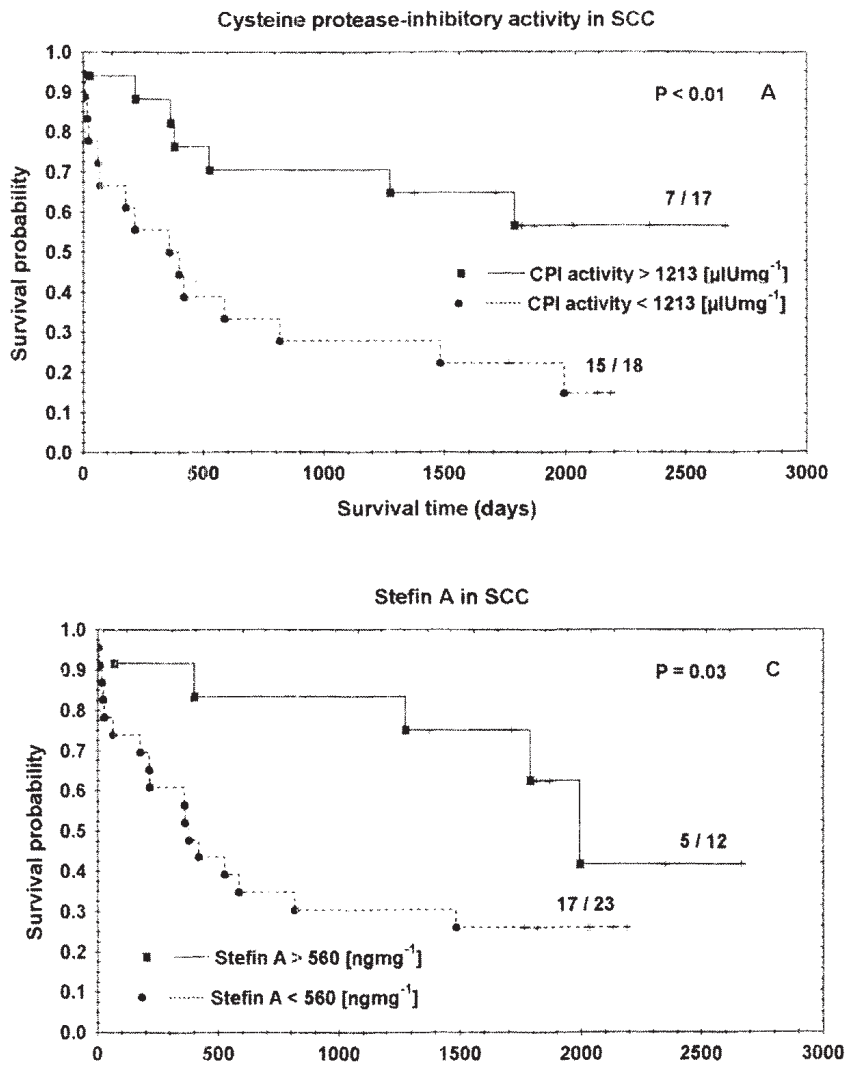

corresponding increase of cysteine protease inhibitors, are involved in remodelling and degradation of extracellular matrix proteins, a proteolytic event associated with tumour spread, invasion and metastasis (36). An enhanced expression of cystatins would be expected to diminish the tumour-associated proteolytic activity and indeed, there is evidence of a suppressive role of tumour-associated cystatins

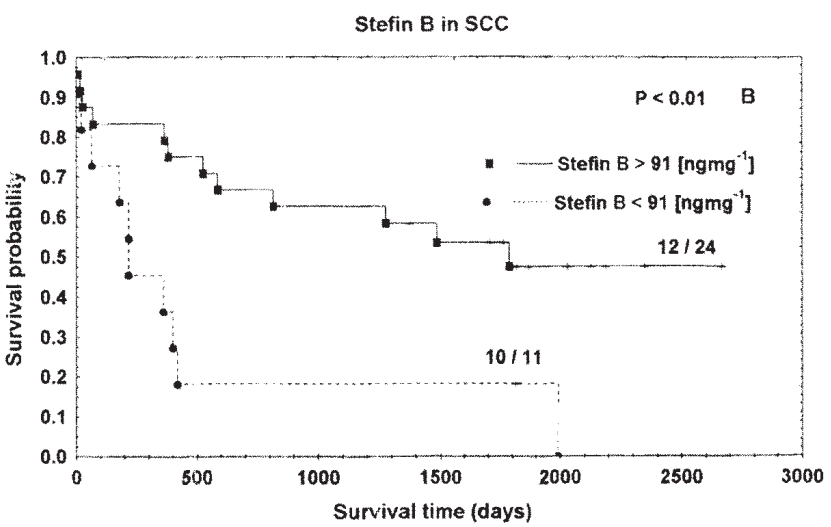

Figure 2. (A) Prognostic significance of CPI activity. (B) Prognostic significance of stefin B levels in tumours of patients with SCC. (C) Prognostic significance of stefin A levels in tumours of patients with SCC. In all three cases, patients with levels below the cut-off value had a significantly shorter overall survival than those with the levels above the

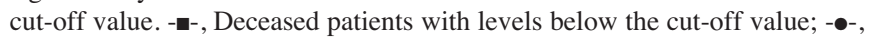
deceased patients with levels above the cut-off value; -|-, patients still living.

in various cancer types $(21,37)$. Moreover, increased levels of stefins A, B and cystatin C in tumour tissues have been shown to correlate with a favourable prognosis of cancer patients $(8,38,39)$.

In contrast, animal models with an excluded expression of particular cystatin do not support a suppressive function for CPI in cancer. In cystatin C (40) and stefin B (Kos et al 
Table IV . Cox regression analysis of NSCLC patients.

\begin{tabular}{llll}
\hline Variable & \multicolumn{1}{c}{$\begin{array}{c}\text { Unfavourable vs favourable } \\
\text { characteristics }\end{array}$} & $\begin{array}{c}\text { Relative } \\
\text { risk }\end{array}$ & P-value \\
\hline $\begin{array}{l}\text { pTNM- } \\
\text { staging }\end{array}$ & TNM IIIb, IV vs TNM I, II, IIIa & 3.5 & $<0.0001$ \\
pT & pT1 vs pT2 vs pT3 vs pT4 & - & n.s. \\
pN & pN0 vs pN1 vs pN2 vs pN3 & - & n.s. \\
Histology & Squamous- vs Adenocarcinoma & - & n.s. \\
CPI activity & $>1131$ vs $<1131 \mu$ IUmg $^{-1}$ protein $^{-1}$ & 1.5 & 0.03 \\
Stefin A & $>560$ vs $<560$ ngmg $^{-1}$ protein $^{-1}$ & 1.5 & 0.03 \\
Stefin B & $>91$ vs $<91$ ngmg $^{-1}$ protein $^{-1}$ & 1.5 & 0.03 \\
\hline
\end{tabular}

unpublished data) knock-out mice, a significantly lower metastatic spread was detected than in wild-type animals. Similarly, higher levels of stefins A, B and cystatin C in body fluids have been associated with a poor prognosis of cancer patients (41). Alterations in secretion may result in higher extracellular and lower intracellular levels of cystatins and, therefore, a reverse correlation with patient survival is to be expected. However, cysteine proteases, and consequently their inhibitors, are involved in various physiological processes, including those which may act in a manner opposing tumour progression, such as apoptosis (42), activation of T-cell immune response $(43,44)$ and cell migration and seeding $(40)$. Thus, besides their concentration, the cell and tissue localization of cystatins could also make a critical switch between harmless and harmful.

Different biochemical properties of cystatins provide another reason for their distinct function in cancer processes. In general, all cystatins are tight binding inhibitors of the $\mathrm{C} 1$ family of cysteine proteases, including human cathepsins B, $\mathrm{H}, \mathrm{L}, \mathrm{K}, \mathrm{S}$; however, the inhibitory profile of a particular cystatin is rather specific. For example, stefin B is a much weaker inhibitor of cathepsin B than the structurally related stefin A (45). Also, cystatin F does not inhibit cathepsin B whereas cystatin $C$, a related type II cystatin, has a high affinity for it (46). Moreover, in contrast to stefins A and B, the type II cystatins $\mathrm{C}, \mathrm{E} / \mathrm{M}$ and $\mathrm{F}$, possess a second reactive site for inhibiting the $\mathrm{C} 13$ family of cysteine proteases (legumain) presumed to be involved in antigen presentation (47). Type II cystatins also exhibit functions that are not related to protease inhibition such as regulation of growth factors or induction of cytokines $(4,6,7)$. Besides specific binding the secretion of type II but not type I cystatins may also regulate the inhibitory potential against intracellular and extracellular targets.

In this study we observed a clear distinction between type I and type II cystatins with regard to their concentration in lung tumours. The levels of stefins A and B were both higher in tumour tissues than in their control counterparts whereas type II cystatins $\mathrm{C}$ and $\mathrm{E} / \mathrm{M}$ were lower in tumour tissues. Such an inhibitory profile could significantly enhance the proteolytic activities of intracellular endopeptidases, such as cathepsins $\mathrm{L}$ and $\mathrm{S}$, which are less effectively inhibited by stefins than by type II cystatins, but only to a lower extent by the activity of cathepsin B. However, stefins are cytosolic inhibitors whereas cathepsins are localized in lysosomes and their possible interaction still needs to be discovered.

On immunohistochemical analysis, type I and type II cystatins showed intense staining in tumour cells and also in the surrounding histiocytes, predominantly macrophages, similar to that reported for cathepsins B and L, which were found in large amounts in tumour cells and histiocytes in lung and other tumours $(8,15)$. It has been suggested that the histiocytes could be a major source of harmful tumour-associated proteolytic activity (36) and, therefore, the localization of cystatins in this cell type does not necessarily mean successful inactivation of their targets. Cystatin F was also detected in tumour cells and histiocytes. Although cystatin F is a type II cystatin, it was found intracellularly in lysosomelike vesicles and due to its inhibitory properties it could effectively impair the endopeptidase activity of cathepsins L, K, V and F (46). Previously its expression was reported to be restricted to haematopoietic cells, very likely involved in processes of the immune response. The demonstration here of cystatin F in primary tumours, together with the reported overexpression of cystatin F mRNA in liver metastatic tumours by Morita et al (48) suggests a function other than regulation of the immune response. mRNA for cystatin E/M has also been reported to be more highly expressed in metastatic oropharingeal squamous cell carcinoma than in primary tumours (49). In this study we did not find any difference in its protein levels in primary and secondary lung tumours, and our results are consistent with those of Sotiropoulu et al (50) showing down-regulation of cystatin $\mathrm{E} / \mathrm{M}$ in breast cancer.

The prognostic information concurs with the concept of different roles in malignant disease for type I and type II cystatins. Stefin A and stefin B showed a significant prognostic value in patients with NSCLC, and patients with high levels of stefins A or B exhibited better prognosis than those with low stefin levels. The same held true for total CPI activity, whereas the levels of cystatins $\mathrm{C}$ and $\mathrm{E} / \mathrm{M}$ did not correlate with survival. For NSCLC patients the stage of the disease and the histological cell type are the most important factors used in clinical routine. In multivariate analysis we statistically weighted stefin A, stefin B and CPI activity with these two established factors to assess their relative prognostic impact. pTNM staging remained the most powerful predictor of survival for NSCLC patients, however, stefin A, stefin B and CPI activity also proved to be independent prognostic factors, enabling eventually better prognostic discrimination between low- and high-risk lung cancer patients than the use of the established factors alone. Furthermore, stefins A and B may provide prognostic information separately for both sub-types of NSCLC, i.e. SCC and AC. The present results confirm our previously reported increased levels of stefins A and B in lung tumours (13) and are consistent with those of Krepela et al (17) who demonstrated a significant increase of stefin A in lung tumours. Similarly, the studies on head and neck carcinomas also provided a strong positive association between levels of stefins A and B and survival probability (39).

In conclusion, our results indicate that cystatins are implicated in the progression of lung cancer and suggest two 
distinct pathways by which cysteine proteases are regulated in lung tumours. Type I cystatins, stefins A and B are upregulated in tumour tissue and, to a certain extent could counter-balance the over-expressed tumour-associated proteolytic activity. Their function as tumour suppressors is supported by survival analysis, which associated their high levels with a better outcome of cancer patients. In contrast, however, type II cystatins $\mathrm{C}$ and $\mathrm{E} / \mathrm{M}$ are down-regulated in lung tumours. Although their role remains protective within the tumour, their lower levels could allow a surplus of harmful tumour-associated proteolytic activity. Further studies are needed to clarify the still elusive regulation of selected cystatins in tumour tissue, their role in the interplay between tumour and stroma cells and the relevance of the uptake of extra-cellular cystatins by these cells for intracellular proteolysis. Additionally, more studies with a larger number of patients need to be carried out to evaluate the prognostic strength and potential clinical use of stefins A and $\mathrm{B}$ in NSCLC patients.

\section{Acknowledgements}

The authors are grateful to Wolfgang Klein, Beate Schauffler, Theresia Trull and Anne-Cathrine Löfström for their excellent technical assistance, to Dr Hans Knoch, Dr Clemens Kraft, Alexander Staib and Johannes Schumacher for providing tissue homogenates and clinical data on lung cancer patients and to Dr Katarina Håkansson for helpful discussions. We thank Dr Heinrich Bülzebruck and Dr Werner Rittgen for their support with the statistical evaluation and Professor Roger Pain for critical reading of the manuscript. This study was supported by the Erwin-Riesch Stiftung, Swedish Medical Research Council (project no. 09915), Ministry of High Education, Science and Technology of the Republic of Slovenia and 6th EU Framework IP project Cancer Degradome.

\section{References}

1. Rawlings ND and Barrett AJ: Evolution of proteins of the cystatin superfamily. J Mol Evol 30: 60-71, 1999.

2. Henskens YMC, Veerman ECI and Amerongen AVN: Cystatins in health and diseases. Biol Chem Hoppe-Seyler 377: 71-86, 1996.

3. Pierre P and Mellman I: Developmental regulation of invariant chain proteolysis controls MHC class II trafficking in mouse dendritic cells. Cell 93: 1135-1145, 1998.

4. Verdot L, Lalmanach G, Vercruysse V, Hoebeke J, Gauthier F and Vray B: Chicken cystatin stimulates nitric oxide release from interferon-g-activated mouse peritoneal macrophages via cytokine synthesis. Eur J Biochem 266: 1111-1117, 1999.

5. Giaimo R, Riccio M, Santi S, Galeotti C, Ambrosetti DC and Melli M: New insights into the molecular basis of progressive myoclonus epilepsy. A multiprotein complex with cystatin B. Hum Mol Genet 23: 2941-2950, 2002.

6. Taupin P, Ray J, Fischer WH, et al: FGF-2-responsive neural stem cell proliferation requires $\mathrm{CCg}$, a novel autocrine/paracrine cofactor. Neuron 28: 385-390, 2000.

7. Sokol JP and Schiemann WP: Cystatin C antagonizes transforming growth factor beta signaling in normal and cancer cells. Mol Cancer Res 2: 183-189, 2004.

8. Kos J and Lah TT: Cysteine proteinases and their endogenous inhibitors: Target proteins for prognosis, diagnosis and therapy in cancer (Review). Oncol Rep 5: 1349-1361, 1998.

9. Pennacchio LA, Lehejoski AE, Stone NE, et al: Mutations in the gene encoding cystatin B in progressive myoclonus epilepsy (EPM1). Science 271: 1731-1734, 1996.

10. Palsdottir M, Abrahamson M, Thorsteinsson L, Arnason A, Olafsson I, Grubb A and Jensson O: Mutation in cystatin C gene causes hereditary brain haemorrhage. Lancet 8611: 603-604, 1998.
11. Trefz G, Lüthgens K, Erdel M, Spiess E and Ebert W: Plasminogen activator and cathepsin $\mathrm{B}$ in normal and malignant human lung tissue. J Cancer Res Clin Oncol 115: 50-58, 1998.

12. Sedo A, Krepela E and Kasafirek E: Dipeptidylpeptidase IV, prolylendopeptidase and cathepsin B activities in primary human lung tumors and lung parenchyma. J Cancer Res Clin Oncol 117: 249-253, 1991

13. Ebert W, Knoch H, Werle B, Trefz G, Muley T and Spiess E: Prognostic value of increased lung tumor tissue cathepsin B. Anticancer Res 14: 895-900, 1994.

14. Werle B, Jülke B, Lah T, Spiess E and Ebert W: Cathepsin B fraction active physiological $\mathrm{pH}$ of 7.5 is of prognostic significance in squamous cell carcinoma of human lung. Br J Cancer 75: 1137-1143, 1997.

15. Werle B, Kraft C, Lah TT, Kos J, Schanzenbächer U, Kayser K, Ebert W and Spiess E: Cathepsin B in infiltrated lymph nodes is of prognostic significance for non-small cell lung cancer patients. Cancer 89: 2282-2291, 2000.

16. Krepela E, Kasafirek E, Novak K and Vyklicky J: Increased cathepsin B activity in human lung tumors. Neoplasma 37: 61-70, 1990.

17. Krepela E, Prochazka J, Karova B, Cermak J and Roubkova H: Cysteine proteases and cysteine protease inhibitors in non-small cell lung cancer. Neoplasma 45: 318-331, 1998.

18. Tsushima H, Sumi H, Mihara H, Joronen J and Hopsu-Havu VK: Cysteine proteinase inhibitors in human melanoma transplanted into nude mice. Biol Chem Hoppe-Seyler 369: 243-250, 1988.

19. Sheahan K, Shuja S and Murnane MJ: Cysteine protease activities and tumour development in human colorectal carcinoma. Cancer Res 49: 3809-3814, 1989.

20. Sloane BF, Rozhin J, Robinson D and Honn KV: Role for cathepsin B and cystatins in tumour growth and progression. Biol Chem Hoppe-Seyler 371: 193-198, 1990.

21. Lah TT, Kokalj-Kunovar M, Strukelj B, Pungercar J, BarlicMaganja D, Drobnic-Kosorok M, Kastelic L, Babnik J, Golouh R and Turk V: Stefins and lysosomal cathepsin B, L and D in human breast carcinoma. Int J Cancer 50: 36-44, 1992.

22. Ebert E, Werle B, Jülke B, et al: Expression of cysteine protease inhibitors stefin A, stefin B, and cystatin C in human lung tumor tissue. Adv Exp Med Biol 421: 259-265, 1997.

23. Zore I, Krasovec M, Cimerman N, et al: Cathepsin B/cystatin C complex levels in sera from patients with lung and colorectal cancer. Biol Chem 382: 805-810, 2001.

24. Manegold C and Drings P: Chemotherapie des nichtkleinzelligen Lungenkarzinoms. In: Thoraxtumoren: Diagnostik - Staging gegenwärtiges Therapiekonzept. Drings P and Vogt-Moykopf I (eds). Springer Verlag, Heidelberg, pp310-327, 1998.

25. Schraube P, Kimming B, Latz D, Flentje M and Wannenmacher M: Radiotherapie des Bronchialkarzionms. In: Thoraxtumoren: Diagnostik - Staging - gegenwärtiges Therapiekonzept. Drings $\mathrm{P}$ and Vogt-Moykopf I (eds). Springer Verlag, Heidelberg, pp277-295, 1998.

26. Kayser K and Gabius HJ: Graph theory and the entropy concept in histochemistry. Theoretical consideration, application in histopathology and the combination with receptor-specific approaches. In: Progress in Histochemistry and cytochemistry. Graumann W, Bendayan M, Bosman FT, Heitz PU, Larsson LI and Wolfe HJ (eds). Gustav Fisher, Stuttgart, Jena, Lübeck, Ulm, pp32-39, 1997.

27. Bradford MM: A rapid and sensitive method for the quantitation of microgramm quantities of protein utilizing the principle of protein-dye binding. Anal Biochem 72: 248-254, 1976.

28. Ebert W, Knoch H, Werle B, Treftz G, Muley T and Spiess E: Prognostic value of increased lung tumor tissue cathepsin B. Anticancer Res 14: 895-899, 1994.

29. Kos J, Smid A, Krasevec M, et al: Lysosomal proteases Cathepsins D, B, H, L and their inhibitors stefins A and B in Head and neck cancer. Biol Chem Hoppe-Seyler 376: 401-405, 1995.

30. Olafsson I, Löfberg M, Abrahamson M and Grubb A: Production, characterization and use of monoclonal antibodies against the major extracellular human cysteine proteinase inhibitors cystatin C and kininogen. Scand J Clin Lab Invest 48: 573-582, 1988.

31. Ni J, Abrahamson M, Zhang M, et al: Cystatin E/M, a novel human cysteine proteinase inhibitor with structural resemblance to family 2 cystatins. J Biol Chem 272: 10853-10858, 1997.

32. Ni J, Alvarez-Fernandez M, Danielsson L, et al: Cystatin F is a glycosylated human low-Mr cysteine proteinase inhibitor. J Biol Chem 273: 24797-24804, 1998. 
33. Kaplan EL and Meier P: Nonparametric estimation from incomplete observations. J Am Stat Assoc 53: 457-481, 1958.

34. Cox DR: Regression models and life tables (with discussion): J R Stat Soc 187: 187-220, 1972.

35. Abel U, Berger J and Wiebelt H: Critlevel. An exploratory procedure for the evaluation of quantitative prognostic factors. Methods Inf Med 23: 154-156, 1984.

36. Sameni M, Dosescu J, Moin K and Sloane BF: Functional imaging of proteolysis: Stromal and inflammatory cells increase tumor proteolysis. Mol Imaging 2: 159-175, 2003.

37. Cox JL, Sexton PS, Green TJ and Darmani NA: Inhibition of B16 melanoma metastasis by overexpression of the cysteine protease inhibitor cystatin C. Melanoma Res 9: 369-374, 1999.

38. Strojan P, Budihna M, Smid L, et al: Prognostic significance of cysteine proteinases cathepsins $\mathrm{B}$ and $\mathrm{L}$ and their endogenous inhibitors stefins $A$ and $B$ in patients with squamous cell carcinoma of the head and neck. Clin Cancer Res 6: 1052-1062, 2000.

39. Strojan P, Oblak I, Svetic B, Smid L and Kos J: Cysteine proteinase inhibitor cystatin $\mathrm{C}$ in squamous cell carcinoma of the head and neck: relation to prognosis. Br J Cancer 90: 1961-1968, 2004.

40. Huh CG, Häkansson K, Nathanson CM, et al: Decreased metastatic spread in mice homozygous for a null allele of the cystatin C protease inhibitor gene. J Clin Pathol Mol Pathol 52: 332-340, 1999 .

41. Kos J, Werle B, Lah T and Brunner N: Cysteine proteinases and their inhibitors in extracellular fluids: Markers for diagnosis and prognosis in cancer. Int J Biol Markers 15: 84-89, 2000.

42. Foghsgaard L, Wissing D, Mauch D, et al: Cathepsin B acts as a dominant execution protease in tumor cell apoptosis induced by tumor necrosis factor. J Cell Biology 153: 999-1009, 2001.
43. Chapman HA, Riese JR and Shi GP: Emerging roles for cysteine proteinases in human biology. Annu Rev Physiol 59: 63-88, 1997.

44. Kos J, Sekirnik A, Kopitar G, et al: Cathepsin S in tumours, regional lymph nodes and sera of patients with lung cancer: relation to prognosis. Br J Cancer 85: 1193-1200, 2001.

45. Tate S, Ushioda T, Utsonomiya-Tate N, et al: Solution structure of human cystatin A variant, cystatin A2-98 M65L, by NMR spectroscopy. A possible role of the interaczions between the $\mathrm{N}$ and C-termini to maintain the inhibitory active form of cystatin A. Biochemistry 34: 14637-14648, 1995.

46. Langerholc T, Zavasnik-Bergant V, Turk B, Turk V, Abrahamson M and Kos J: Inhibitory properties of cystatin F and its localisation in U937 promonocyte cells. FEBS J 272: $1535-1545,2005$.

47. Alvarez-Fernandez M, Barrett AJ, Gerhartz B, Dandi PM, Ni J and Abrahamson M: Inhibition of mammalian legumain by some cystatins is due to a novel second reactive site. J Biol Chem 274: 19195-19203, 1999.

48. Morita M, Hara Y, Tamai Y, Arakawa H and Nishimura S Genomic construct and mapping of the gene for CMAP (leukocystatin/cystatin F, CST7) and identification of a proximal novel gene BSCv (C20orf3). Genomics 67: 87-91, 2000.

49. Vigneswaran $\mathrm{N}, \mathrm{Wu} \mathrm{J}$ and Zacharias W: Upregulation of cystatin $\mathrm{M}$ during the progression of oropharyngeal squamous cell carcinoma from primary tumour to metastasis. Eur J Cancer B Oral Oncol 39: 559-568, 2003.

50. Sotiropoulu G, Anisowicz A and Sager R: Identification, cloning, and characterisation of cystatin $\mathrm{M}$, a novel cysteine proteinase inhibitor, down-regulated in breast cancer. J Biol Chem 272: 903-910, 1997. 